\title{
Five new species from the subfamily Entiminae (Coleoptera: Curculionidae) in Dominican amber
}

\author{
George Poinar, Jr. and Andrei A. Legalov
}

\begin{abstract}
Five new species of Entiminae weevils are described from Dominican amber: Diaprepes squamula sp. nov., resembling $D$. famelicus (Olivier, 1790) from the West Indies; Lachnopus serraticrus sp. nov., resembling L. acuticollis (Gyllenhal, 1834) from Cuba and L. proteus (Olivier, 1807) from Hispaniola in the tribe Eustylini; Apodrosus tinctocorpus sp. nov., resembling A. andersoni Girón and Franz, 2010 and A. quisqueyanus Girón and Franz, 2010 from Hispaniola; Apodrosus canalinasus sp. nov., resembling A. viridium Girón and Franz, 2010 from Hispaniola in the tribe Polydrusini; and Promecops divarichela sp. nov., resembling $P$. uniformis Champion, 1911 from Guatemala and $P$. alternans Champion, 1911 from Central America in the tribe Eudiagogini. These are the first descriptions of representatives of the genera Apodrosus, Diaprepes, and Lachnopus in Dominican amber.
\end{abstract}

George Poinar, Jr. Department of Integrative Biology, Oregon State University, Corvallis, Oregon 97331, USA.poinarg@science.oregonstate.edu

Andrei A. Legalov. Laboratory of Phylogeny and Faunogenesis, Institute of Systematics and Ecology of Animals, Siberian Branch, Russian Academy of Sciences, Frunze street, 11, Novosibirsk 630091, Russia. fossilweevils@gmail.com

Keywords: Curculionoidea; Apodrosus, Promecops, Diaprepes, Lachnopus; new species; Tertiary weevils Submission: 10 July 2016 Acceptance: 1 May 2017

\section{INTRODUCTION}

Curculionidae is one of the most speciose and widespread beetle families. Weevils play important roles in various ecosystems. The oldest weevils are known from the Aptian of Mongolia (Legalov, 2014), but they become more diverse during the Upper Cretaceous (Legalov, 2012). The subfamily Entiminae is one of the largest among the weevils.
In this group, there was an expansion of trophic relationships that resulted in the larvae developing on plant roots in the soil near the roots and the loss of a number of specific features in the imago. The earliest fossil Entiminae was described from Lower Eocene Fushun amber (Hong, 2002). During the Eocene, this group developed in both sedimentary deposits and amber (Yunakov and Kirejtshuk,

http://zoobank.org/826DC223-3C83-4FF5-9C8E-CE567C59CA51

Poinar, George Jr. and Legalov, Andrei A. 2017. Five new species from the subfamily Entiminae (Coleoptera: Curculionidae) in Dominican amber. Palaeontologia Electronica 20.2.21A: 1-13

palaeo-electronica.org/content/2017/1799-new-entiminae-in-amber 
2011; Legalov, 2015). Only two species from the tribes Eudiagogini and Naupactini have been described previously from Dominican amber (Poinar and Brown, 2011; Poinar et al., 2013). The present study describes an additional five species in the tribes Eustylini, Polydrusini, and Eudiagogini, thus expanding our knowledge of the Neotropical fauna of this subfamily.

\section{MATERIAL AND METHODS}

The specimens were obtained from mines in the Cordillera Septentrional of the Dominican Republic. Dating of Dominican amber is still controversial, with the latest purposed age of 20-15 mya based on foraminifera (Iturralde-Vinent and MacPhee, 1996) and the earliest as 45-30 mya based on coccoliths (Schlee, 1990). In addition, Dominican amber is secondarily deposited in sedimentary rocks, which makes a definite age determination difficult (Poinar and Mastalerz, 2000). A range of ages for Dominican amber is possible as the amber is associated with turbiditic sandstones of the Upper Eocene to Lower Miocene Mamey Group (Draper et al., 1994). Dominican amber was produced by the leguminous tree, Hymenaea protera Poinar, 1991 and a reconstruction of the Dominican amber forest based on amber fossils indicated that the environment was similar to that of a present-day tropical moist forest (Poinar and Poinar, 1999). Observations and photographs were made with a Nikon SMZ-10 stereoscopic microscope (Tokyo, Japan) and Zeiss Stemi 2000-C binocular microscope (Jena, Germany). Helicon Focus Pro X64 (New York, USA) was used to stack photos for better clarity and depth of field.

\section{SYSTEMATIC PALEONTOLOGY}

Tribe EUSTYLINI Lacordaire, 1863

Genus DIAPREPES Schoenherr, 1823

Diaprepes squamula sp. nov.

Figures 1, 2

zoobank.org/198C4775-FB64-4047-821F-1F44799C7062

Holotype. Deposited in the American Museum of Natural History (New York, USA) (AMNH no. DR10-992).

Description. The specimen is complete. Body length (without rostrum), $9.0 \mathrm{~mm}$; rostrum length, $0.6 \mathrm{~mm}$. Body black, with dense light, rounded, and appressed scales.

Head $1.2 x$ as long as rostrum, not constricted behind eye; rostrum almost straight, short, $0.5 \mathrm{x}$ as long as pronotum, $0.9 x$ as narrow as wide at apex,
$1.1 \mathrm{x}$ as wide as wide in middle and at base, densely punctate; lateral margins of rostrum weak widened to eyes; epistoma indistinct; forehead quite narrow, narrower than rostrum base width, flattened; eyes large, convex, rounded; temples quite short, $0.7 x$ as long as eye; antennal scrobes reaching lower margin of eye; pterygia dorso-lateral; geniculate antennae long, inserted in apical third of rostrum, reaching base of elytra; antennomeres almost conical; 1st antennomere (scape) $7.3 x$ longer than wide, reaching base of eye; 2 nd4th antennomeres subequal in width; 2nd antennomere $3.7 x$ longer than wide, $0.5 x$ as long as 1 st antennomere; 3rd antennomere 4.0x longer than wide, $1.1 \mathrm{x}$ as long as $2 \mathrm{nd}$ antennomere; 4 th antennomere $2.3 x$ longer than wide, $0.6 x$ as long as $3 r d$ antennomere; 5th antennomere $2.4 x$ longer than wide, $0.9 x$ as long and $0.8 x$ as narrow as 4 th antennomere; 6th antennomere 2.0x longer than wide, $0.8 \mathrm{x}$ as long as and equal in width to 5 th antennomere; 7 th antennomere $2.0 x$ longer than wide, $1.2 x$ as long as and $1.2 x$ as wide as 6 th antennomere; 8th antennomere $2.3 x$ longer than wide, $1.2 x$ as long as and subequal in width to 7 th antennomere; club compact, 3.0x longer than wide, $0.3 x$ as long as flagellum, with fused articles.

Pronotum bell-shaped, 1.1x longer than wide at apex, $0.8 x$ longer than wide in middle, $0.9 x$ longer than wide at base; densely punctate, weakly flattened, $0.7 x$ as narrow as elytral base; sides weakly curved; scutellum trapezoidal.

Elytra elongate and convex, $4.5 \mathrm{x}$ as long as pronotum, $2.7 x$ longer than wide at base, $2.2 x$ as long as wide in middle, $4.9 x$ longer than wide at apical fourth; humeri weakly convex; punctate striae distinct, with small points; intervals weakly convex, 3.3-4.0x as wide as diameter of points; apical part of elytra not convex laterally.

Prosternum weakly convex, densely rugosepunctate, with vibrissae but without postorbital lobe; precoxal portion of prosternum $0.3 x$ as long as procoxal cavities and $0.5 x$ as long as postcoxal portion; postcoxal portion of prosternum 2.0x as long as precoxal portion and $0.5 x$ as long as procoxal cavities; procoxal cavities connected; metasternum convex, punctate; metepisternum narrow, $10.0 x$ as long as wide in middle.

Abdomen convex, densely punctate; 1st, 2nd, and 5 th ventrites elongate; 1 st ventrite $1.1 \mathrm{x}$ as long as metacoxal cavities length; 2 nd ventrite subequal to 1st ventrite; 3rd and 4th ventrites short, subequal in length; 3rd ventrite $0.6 x$ as long as 2 nd ventrite; 5 th ventrite $2.6 x$ as long as 4 th ventrite. 


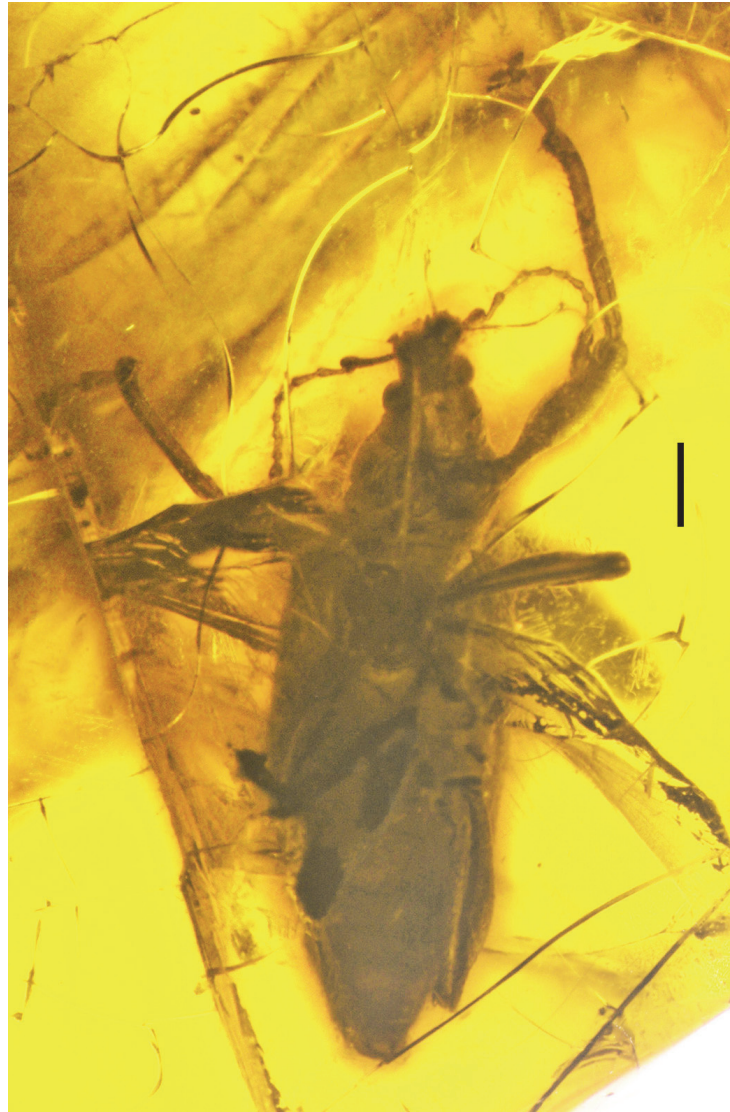

FIGURE 1. Ventral view of Diaprepes squamula n. sp. in Dominican amber. Bar $=1.0 \mathrm{~mm}$.

Procoxae located near middle of prosternum, closer to anterior margin; mesocoxae rounded, narrowly separated; femora thickened, punctate, without teeth; profemora $4.3 x$ longer than wide in middle; mesofemora $4.7 x$ longer than wide in middle; metafemora $4.8 x$ longer than wide in middle; tibiae weakly curved, punctate, not serrated on inner margin, with mucro; protibia 11.3x longer than wide in middle, with long mucro; mesotibia $11.7 x$ longer than wide in middle; meso- and metatibiae with small mucro; metatibial corbel enclosed, without scales; metatibiae reaching 5th ventrite; tarsi elongate; 1st and 2nd tarsomeres conical; 3rd tarsomere bilobed; 5th tarsomere elongate; claws free; protarsi: 1st tarsomere 1.4x longer than wide; 2nd tarsomere $1.5 x$ longer than wide, $1.2 x$ as long as and $1.1 \mathrm{x}$ as wide as 1 st tarsomere; 3rd tarsomere $0.4 x$ longer than wide, $0.5 x$ as long as and $1.8 \mathrm{x}$ as wide as $2 \mathrm{nd}$ tarsomere; 5 th tarsomere $5.0 \mathrm{x}$ longer than wide, $2.5 x$ as long as and $0.2 x$ as narrow as 3rd tarsomere; metatarsi: 1st tarsomere 2.0x longer than wide; 2 nd tarsomere subequal to 1st tarsomere; 3rd tarsomere $0.5 x$ longer than wide, $0.7 x$ as long as and $2.8 x$ as wide as $2 n d$ tar-

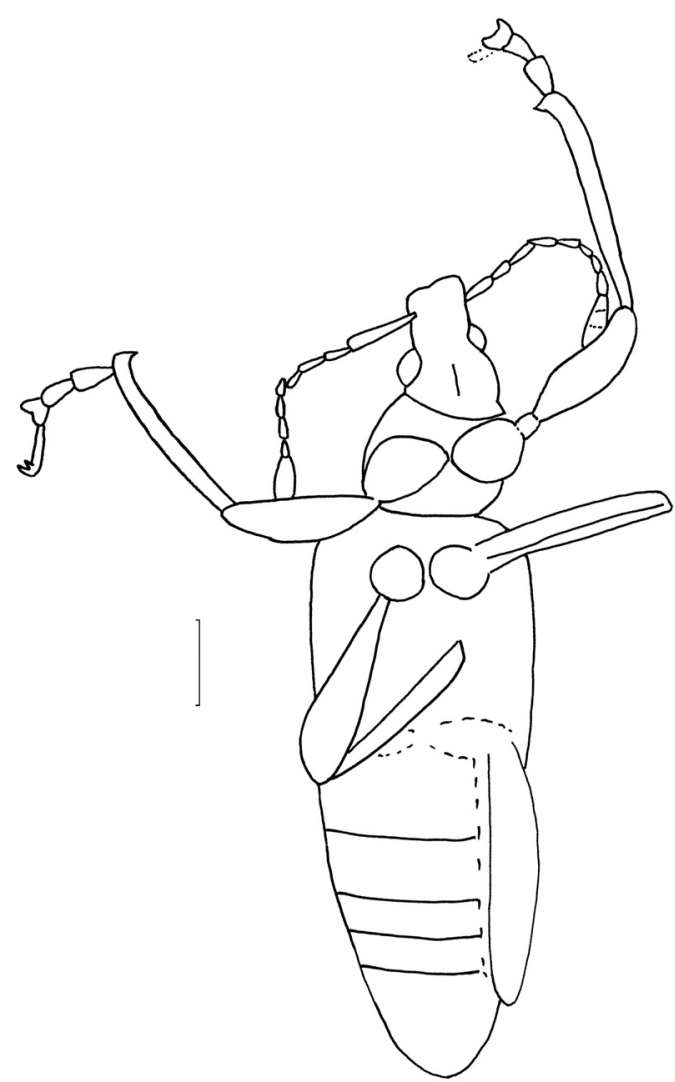

FIGURE 2. Drawing of Diaprepes squamula n. sp. in ventral view. Scale bar equals $1.1 \mathrm{~mm}$.

somere; 5 th tarsomere $3.8 \mathrm{x}$ longer than wide, $2.1 \mathrm{x}$ as long as and $0.3 x$ as narrow as 3rd tarsomere.

Type locality. Amber mine in the northern portion of the Dominican Republic.

Etymology. The species epithet is taken from the Latin "squamosus" = scaly in reference to the dense scales covering the body.

Diagnosis. The new species is similar to Diaprepes famelicus (Olivier, 1790) from the West Indies but differs by the tibiae lacking serrations on the inner margin, smaller body size, body with dense scales, a greater convex eye, and wider elytral intervals.

Remarks. This specimen belongs to the tribe Eustylini because the elytra have humeri (Franz, 2012), the metabibial corbel are enclosed, the claws are free, and the pterygia are dorso-lateral. The front margin of the prosternum with vibrissae is a diagnostic character of the genus Diaprepes.

Genus LACHNOPUS Schoenherr, 1840 Lachnopus serraticrus $\mathrm{sp}$. nov. Figures 3-6

zoobank.org/B5C091E2-90E7-48E5-A2D9-D377A3C6969D 


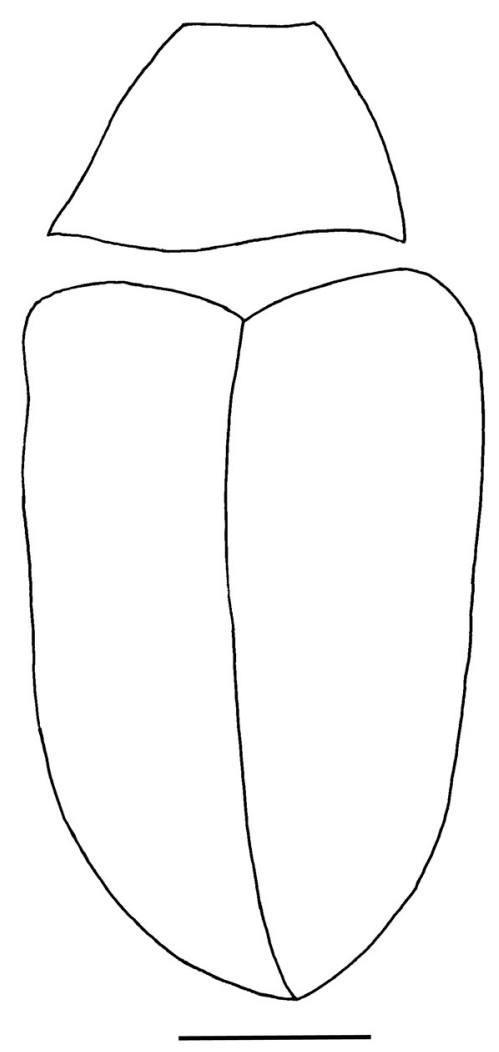

FIGURE 3. Drawing of pronotum and elytra of Lachnopus serraticrus $\mathrm{n}$. $\mathrm{sp}$. in dorsal view. Scale bar equals $1.4 \mathrm{~mm}$.
Holotype. Deposited in Poinar amber collection maintained at Oregon State University, Corvallis (Oregon, USA) (accession \# 14).

Description. The specimen is complete. Body length (without rostrum), $7.5 \mathrm{~mm}$; rostrum length, $1.4 \mathrm{~mm}$. Body black, with glabrous, small, subcircular, and appressed scales.

Head $0.4 x$ as long as rostrum, not constricted behind eye; rostrum weakly curved, short, $0.7 x$ as long as pronotum, finely punctate; lateral margins of rostrum narrowing to eyes; epistoma indistinct; forehead quite narrow, flattened; eyes large, convex, rounded; temples quite short, $0.4 \mathrm{x}$ as long as eye; antennal scrobes directed under eye but not reaching eye; pterygia dorso-lateral; geniculate antennae long, inserted in apical third of rostrum, reaching base of elytra; antennomeres almost conical; 1st antennomere (scape) 7.1x longer than wide, reaching base of eye; 2 nd antennomere $1.7 x$ longer than wide, $0.2 x$ as long as and $0.6 x$ as narrow as 1 st antennomere; 3rd antennomere $2.4 x$ longer than wide, $1.2 x$ as long as and $0.8 x$ as narrow as 2nd antennomere; 4th antennomere 2.0x longer than wide, $0.8 \mathrm{x}$ as long as and equal in width to 3rd antennomere; 6th antennomere $2.5 \mathrm{x}$ longer than wide; 7th antennomere 2.0x longer than wide, $1.2 x$ as long as and $1.5 x$ as wide as 6 th antennomere; 8th antennomere $1.3 x$ longer than wide, $0.8 x$ as long as and $1.3 x$ as narrow as 7 th antennomere; club compact, 3.0x longer than wide, $0.3 x$ as long as flagellum, with fused articles.

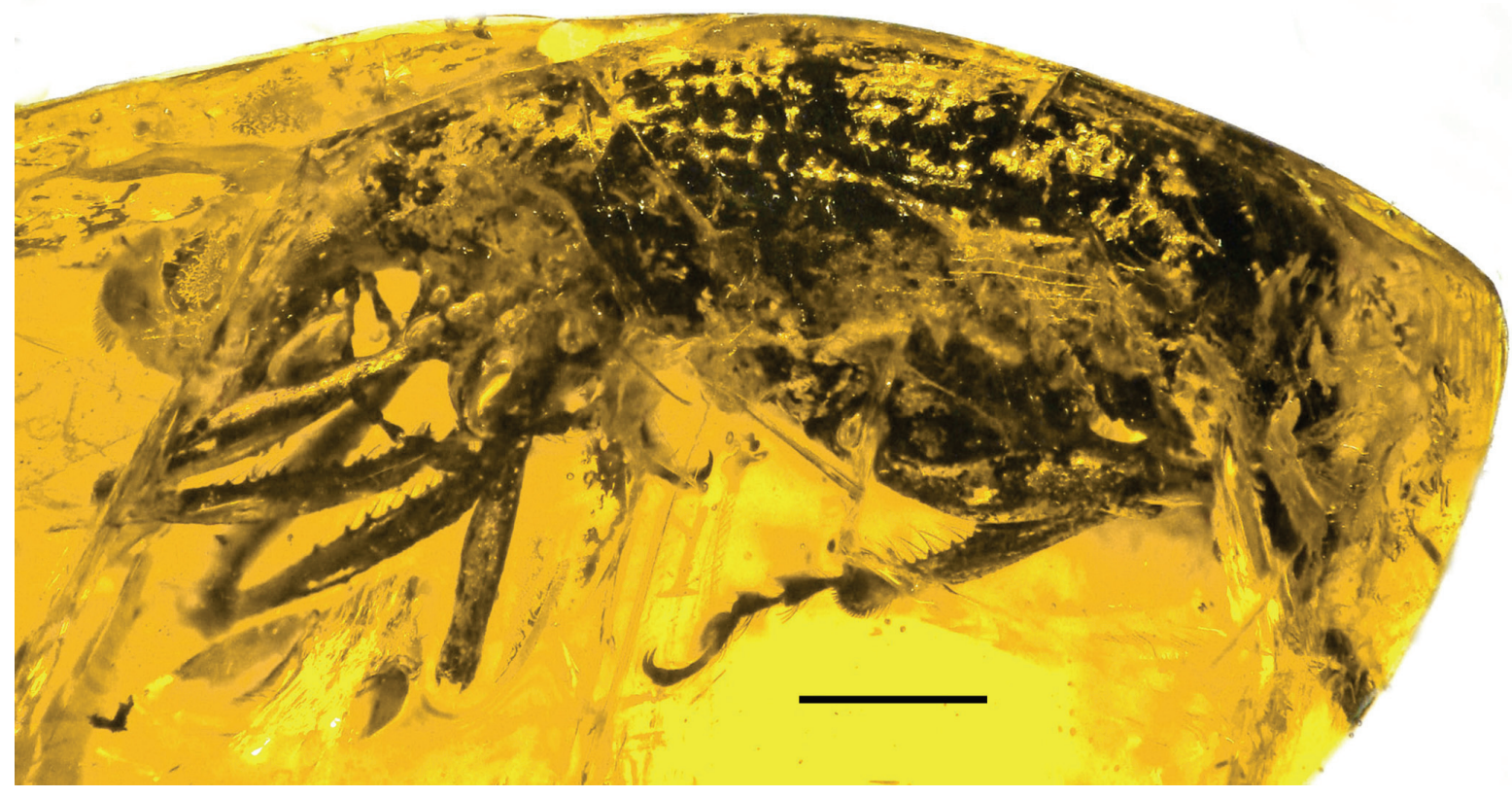

FIGURE 4. Lateral view of Lachnopus serraticrus n. sp. in Dominican amber. Scale bar equals $1.3 \mathrm{~mm}$. 


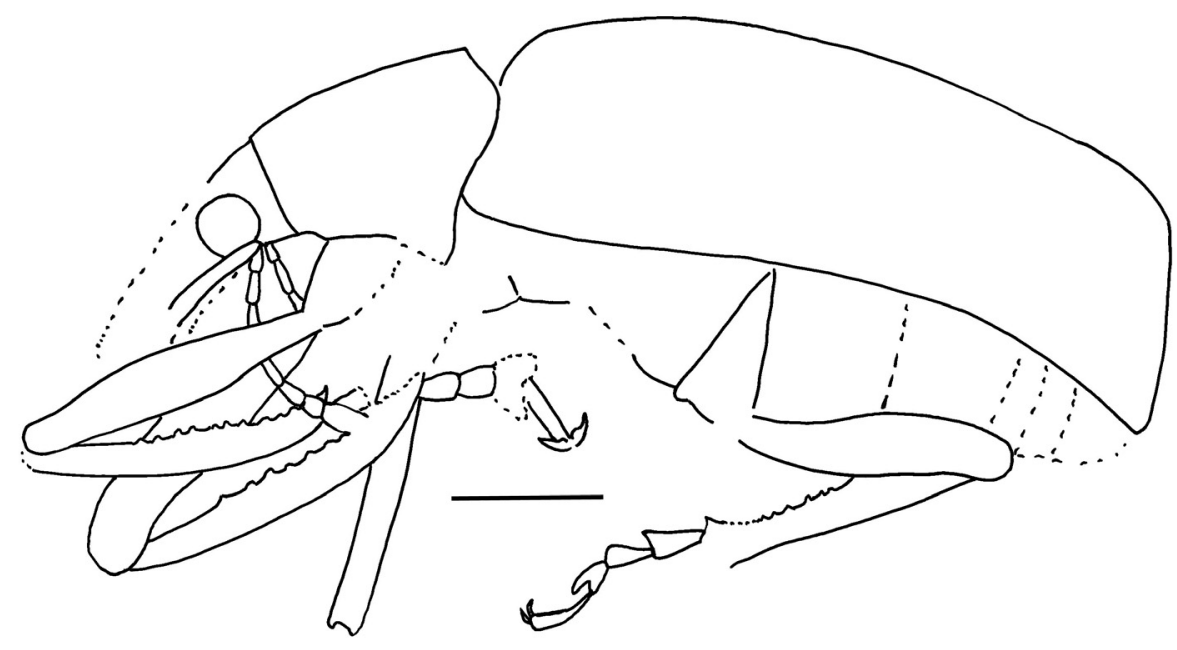

FIGURE 5. Drawing of Lachnopus serraticrus $\mathrm{n}$. $\mathrm{sp}$. in lateral view. Scale bar equals $1.1 \mathrm{~mm}$.

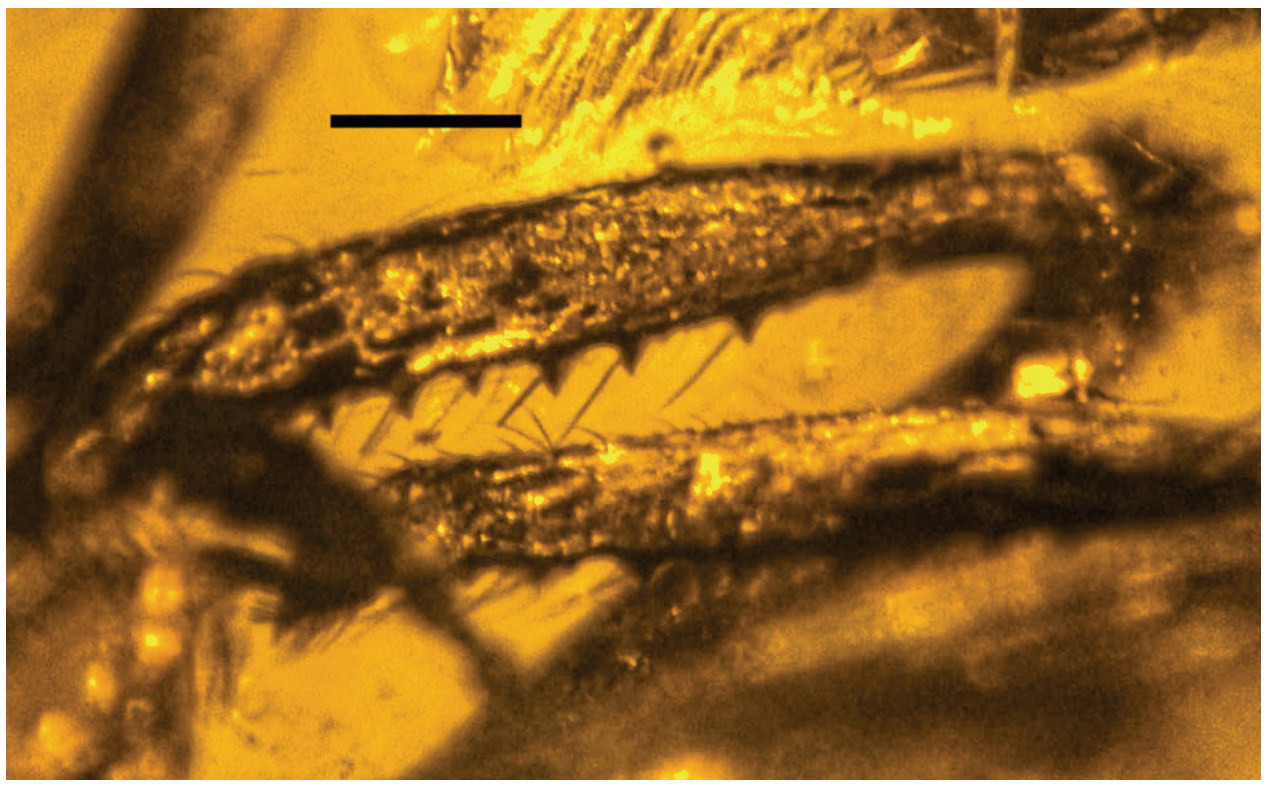

FIGURE 6. Lateral view of protibiae of Lachnopus serraticrus $\mathrm{n}$. sp. in Dominican amber. Scale bar equals $0.4 \mathrm{~mm}$.

Pronotum wide, trapezoidal, $1.7 x$ longer than width at apex, $0.8 x$ longer than wide in middle, $0.6 x$ longer than wide at base; densely punctate, weakly flattened, $0.8 \mathrm{x}$ as narrow as elytral base; sides almost straight; scutellum trapezoidal.

Elytra convex, $3.3 \mathrm{x}$ as long as pronotum, $1.7 \mathrm{x}$ longer than wide at base and in middle, $2.4 x$ longer than wide at apical fourth; humeri weakly convex; punctate striae distinct, with large points; intervals weakly convex, $1.2-1.5 \mathrm{x}$ as wide as diameter of points; apical part of elytra convex laterally.
Prosternum weakly convex, densely punctate, without postorbital lobe and vibrissae; precoxal portion of prosternum $0.3 x$ as long as procoxal cavities and $0.6 x$ as long as postcoxal portion; postcoxal portion of sternum 1.6x as long as precoxal portion and $0.5 x$ as long as procoxal cavities; procoxal cavities connect; metasternum convex, punctate; metepisternum quite narrow.

Abdomen convex, densely punctate; 1st, 2nd and 5 th ventrites elongate; 1 st ventrite $2.0 x$ as long as metacoxal cavities length; 2 nd ventrite subequal to 1 st ventrite; 3rd and 4th ventrites short, equal in 
length; 3 rd ventrite $0.4 \mathrm{x}$ as long as $2 \mathrm{nd}$ ventrite; 5 th ventrite $2.0 x$ as long as 4 th ventrite.

Procoxae located near middle of prosternum, closer to anterior margin; mesocoxae rounded, narrowly separated; femora thickened, punctate, without teeth; profemora $4.8 \mathrm{x}$ longer than wide in middle; metafemora $4.7 x$ longer than wide in middle; tibiae weakly curved, punctate, serrated on inner margin, with mucro; metatibial corbel enclosed, without scales; protibia 6.9x longer than wide in middle; metatibia $7.5 \mathrm{x}$ longer than wide in middle; tarsi elongate; 1st and 2nd tarsomeres conical; 3rd tarsomere bilobed; 5th tarsomere elongate; claws free; protarsi: 1st tarsomere 1.6x longer than wide; 2 nd tarsomere $1.3 x$ longer than wide, subequal in length, $1.2 x$ as wide as 1 st tarsomere; 3rd tarsomere $0.6 \mathrm{x}$ longer than wide, equal in length and $2.2 \mathrm{x}$ as wide as $2 \mathrm{nd}$ tarsomere; 5 th tarsomere $3.8 \mathrm{x}$ longer than wide, $1.9 \mathrm{x}$ as long as and $0.3 x$ as narrow as 3rd tarsomere; metatarsi: 2nd tarsomere $0.8 \mathrm{x}$ as long as 1 st tarsomere; 3rd tarsomere $0.8 \mathrm{x}$ as long as 2 nd tarsomere; 5 th tarsomere $4.3 x$ longer than wide, $1.6 x$ as long as $3 r d$ tarsomere.

Type locality. Amber mine in the northern portion of the Dominican Republic.

Etymology. The species epithet is from the Latin "serratus" = toothed and the Latin "crusis" = leg, in reference to the serrated tibiae.

Diagnosis. The new species is very close to Lachnopus acuticollis (Gyllenhal, 1834) from Cuba but differs by the much smaller body size, narrower elytral intervals, and scape reaching only to the middle of the eye. From L. proteus (Olivier, 1807) from Hispaniola, it differs by having all tibiae serrated on the inner margins, the trapezoidal pronotum, evenly convex eyes, procoxa located further from front margin of prosternum and the apical part of the elytra convex laterally.

Remarks. This species belongs to the tribe Eustylini because the elytra have humeri, the metabibial corbel are enclosed, the claws are free, and the pterygia are dorso-lateral. The front margin of prosternum without vibrissae, trapezoid pronotum, base of elytra slightly wider than pronotum, lateral margins of the rostrum narrowed toward the eyes, and the procoxae located closer to the front margin of the prosternum are diagnostic characters of the genus Lachnopus.

Tribe? POLYDRUSINI Schoenherr, 1823 Genus APODROSUS Marshall, 1922 Apodrosus tinctocorpus sp. nov. Figures 7-9

zoobank.org/F207C3C1-1414-4D80-B3F3-EB0FA723196C
Holotype. Deposited in Poinar amber collection maintained at Oregon State University, Corvallis (Oregon, USA) (accession \# 162).

Description. The specimen is complete. Body length, $5.0 \mathrm{~mm}$; rostrum length, $0.8 \mathrm{~mm}$. Body brown-black, with appressed light oval scales.

Head $0.8 x$ as long as rostrum, not constricted behind eyes; rostrum weakly curved, short, $1.2 \mathrm{x}$ longer than wide at apex, $1.8 x$ longer than wide in middle, $1.6 x$ longer than wide at base, $0.6 x$ as long as pronotum, finely punctate; epistoma large, glabrous, elevated; forehead wide, flattened, $0.8 \mathrm{x}$ as narrow as rostraum base width; eyes large, convex, oval; temples quite long, $0.8 x$ as long as eye; geniculate antennae inserted in middle of rostrum, reaching base of pronotum; pterygia dorso-lateral;

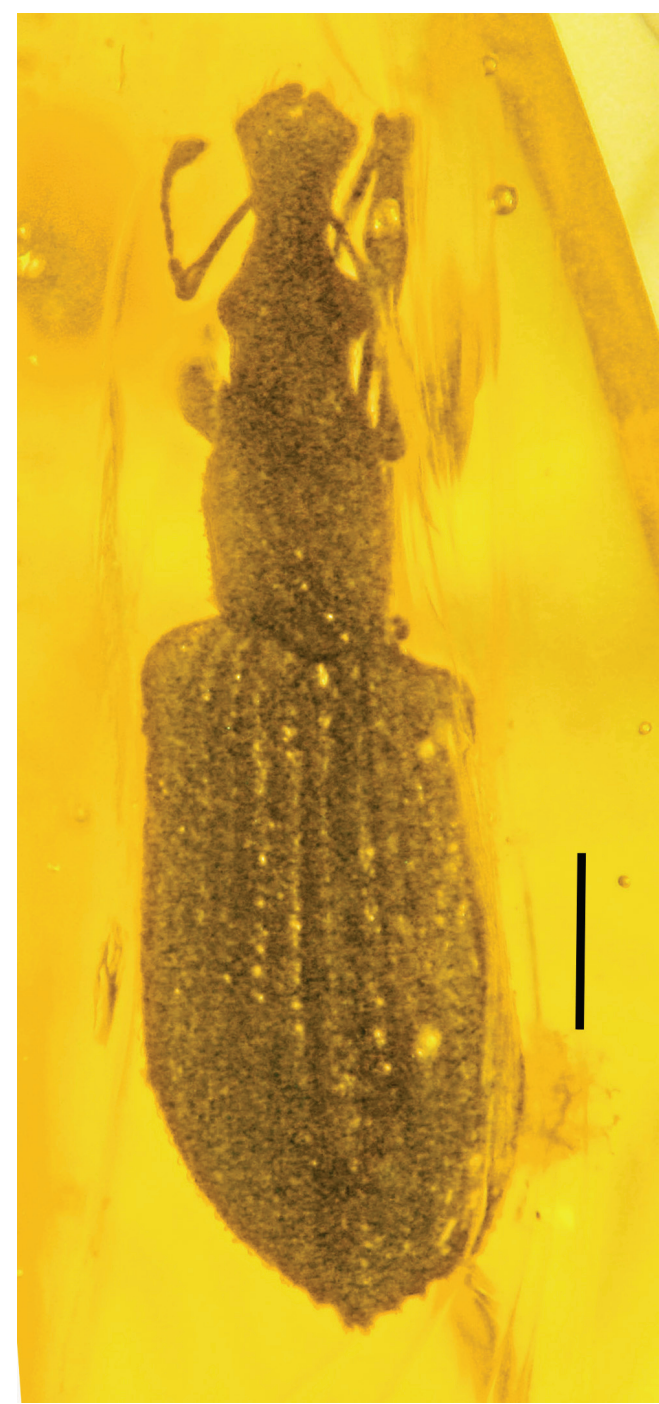

FIGURE 7. Dorsal view of Apodrosus tinctocorpus n. $\mathrm{sp}$. in Dominican amber. Scale bar equals $0.9 \mathrm{~mm}$. 


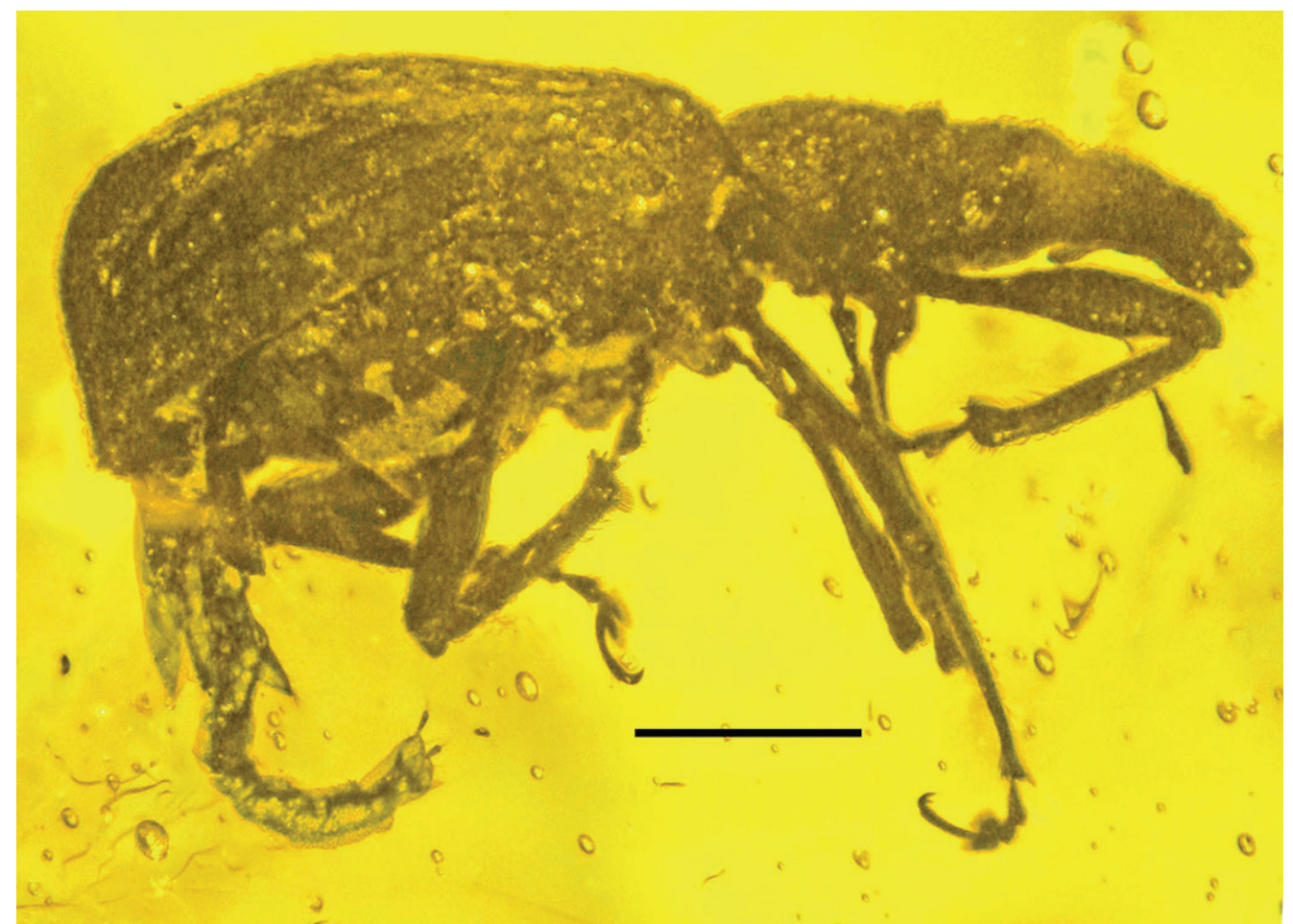

FIGURE 8. Lateral view of Apodrosus tinctocorpus n. sp. in Dominican amber. Scale bar equals $1.2 \mathrm{~mm}$.

antennomeres almost conical; 1st antennomere (scape) $6.7 x$ longer than wide; 2 nd antennomere $2.5 x$ longer than wide, $0.2 x$ as long as and $0.7 x$ as narrow as 1 st antennomere; 3rd antennomere 3.3x longer than wide, $0.9 x$ as long as and $0.7 x$ as narrow as 2nd antennomere; 4th antennomere $1.8 x$ longer than wide, $0.5 \mathrm{x}$ as long as and equal in width to 4th antennomere; 5th antennomere $1.3 x$ longer than wide, $0.9 \mathrm{x}$ as long as and $1.1 \mathrm{x}$ as wide as 4 th antennomere; 6 th antennomere $1.1 \mathrm{x}$ longer than wide, $0.8 \mathrm{x}$ as long as and equal in width to 5 th antennomere; 6 th-7th antennomeres subequal in length; 7th antennomere equal to 8th antennomere; 8th antennomere equal in length and width, $0.8 x$ as long as and $0.9 x$ as narrow as 7 th antennomere; club compact, $2.1 \mathrm{x}$ longer than wide, $0.1 \mathrm{x}$ as long as flagellum, with fused articles.

Pronotum quite long, $2.1 \mathrm{x}$ longer than wide at apex, $1.4 x$ longer than wide in middle, $1.6 x$ longer than wide at base; densely punctate, weakly flattened, distinctly narrower than elytral base; sides almost straight; scutellum trapezoidal.

Elytra convex, $2.7 x$ as long as pronotum, 2.6x longer than wide at base, $2.1 \mathrm{x}$ longer than wide in middle, 3.6x longer than wide at apical fourth; humeri convex; punctate striae distinct, with quite large points; intervals weakly convex, quite wide, 2.0-3.3x as wide as diameter of points; apical part of elytra convex laterally.

Prosternum weakly convex, densely punctate, without postorbital lobe, and vibrissae; pre- and postcoxal portions of prosternum long; procoxal

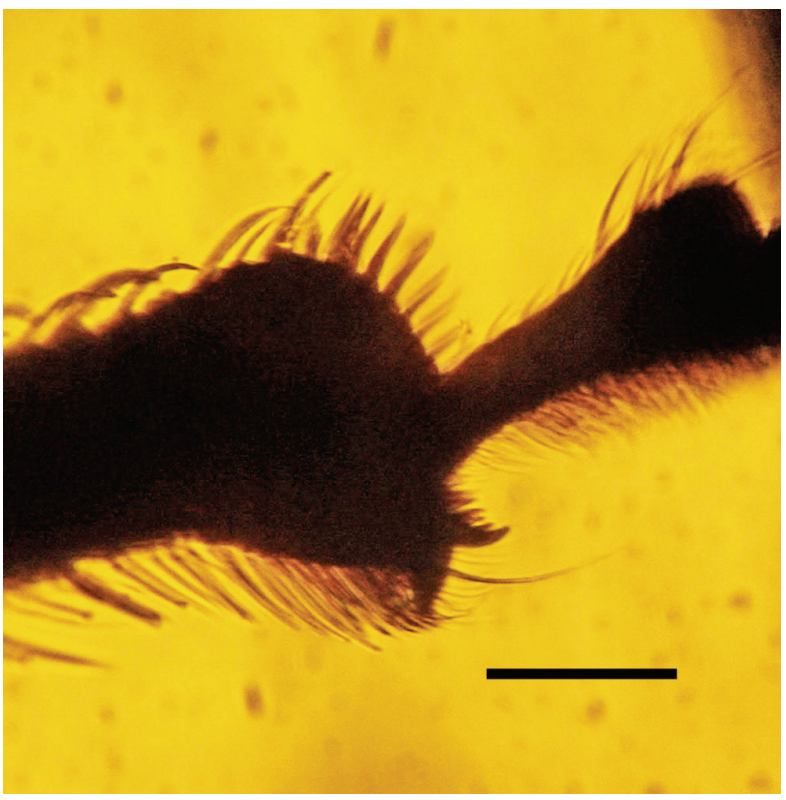

FIGURE 9. Lateral view of apex of metatibia of Apodrosus tinctocorpus $\mathrm{n}$. sp. in Dominican amber. Scale bar equals $0.2 \mathrm{~mm}$. 
cavities connect; metasternum weakly convex, punctate; metepisternum quite narrow.

Abdomen flattened, finely punctate; 1 st, $2^{\text {nd }}$, and 5th ventrites elongate; 3rd and 4th ventrites short.

Procoxae located near middle of prosternum; mesocoxae rounded, narrowly separated; prolegs not increased in size; femora thickened, punctate, without teeth; profemora 5.2x longer than wide in middle; metafemora 5.1x longer than wide in middle; tibiae almost straight, punctate, with mucro and premucro; protibia 6.7x longer than wide in middle; metatibia 7.6x longer than wide in middle; metatibial corbel semi-enclosed; tarsi elongate; 1 st tarsomere elongate; 2nd tarsomere conical; 3rd tarsomere bilobed; 5th tarsomere elongate; claws connate; protarsi: 2nd tarsomere $0.7 x$ as long as 1st tarsomere; 3rd tarsomere equal in length to 2nd tarsomere; 5th tarsomere $2.5 \mathrm{x}$ as long as 3rd tarsomere; metatarsi: 3rd tarsomere subequal in length to 2 nd tarsomere; 5th tarsomere $1.5 \mathrm{x}$ as long as 3rd tarsomere.

Type locality. Amber mine in the northern portion of the Dominican Republic.

Etymology. The species epithet is taken from the Latin "tinctus" = dyed and the Latin "corpus" = body, in reference to the unicolored body.

Diagnosis. The new species is close to Apodrosus andersoni Girón and Franz, 2010 from Hispaniola but differs by the shorter scape, narrower pronotum, elytral intervals without erect setae, apical part of elytra convex laterally, and larger body sizes. From A. quisqueyanus Girón and Franz, 2010 from Hispaniola, it differs by the unicolored body, longer rostrum, narrower pronotum, and wider eye.

Remarks. This and the following new species belong to the tribe Polydrusini because the pterygia are dorso-lateral, the claws are connate, the head is not constricted behind the eyes, and the prolegs are not widened (van Emden, 1944). The tibiae with a promucro and mucro, the semienclosed metatibial corbel and the large, elevated epistoma of these species are characters of the genus Apodrosus.

Apodrosus canalinasus sp. nov.

Figures 10, 11

zoobank.org/7D80B90D-533A-4EA9-8103-02D4BA764B33

Holotype. Deposited in Poinar amber collection maintained at Oregon State University, Corvallis (Oregon, USA) (accession \# 25).

Description. The specimen is complete. Body length (without rostrum), $4.5 \mathrm{~mm}$; rostrum length,
$0.8 \mathrm{~mm}$. Body brown-black, with dense appressed light oval scales.

Head not constricted behind eyes; rostrum almost straight, short, 1.0x longer than wide at apex, $1.2 x$ longer than wide in middle, $1.0 x$ longer than wide at base, $0.6 \mathrm{x}$ as long as pronotum, densely punctate; rostrum and forehead with longitudinal mid-furrow; epistoma large, naked, and elevated; forehead wide, very weakly impressed, $0.8 \mathrm{x}$ as narrow as rostrum base width; eyes large, weakly convex, oval; temples present; geniculate antennae inserted behind middle of rostrum, reach-

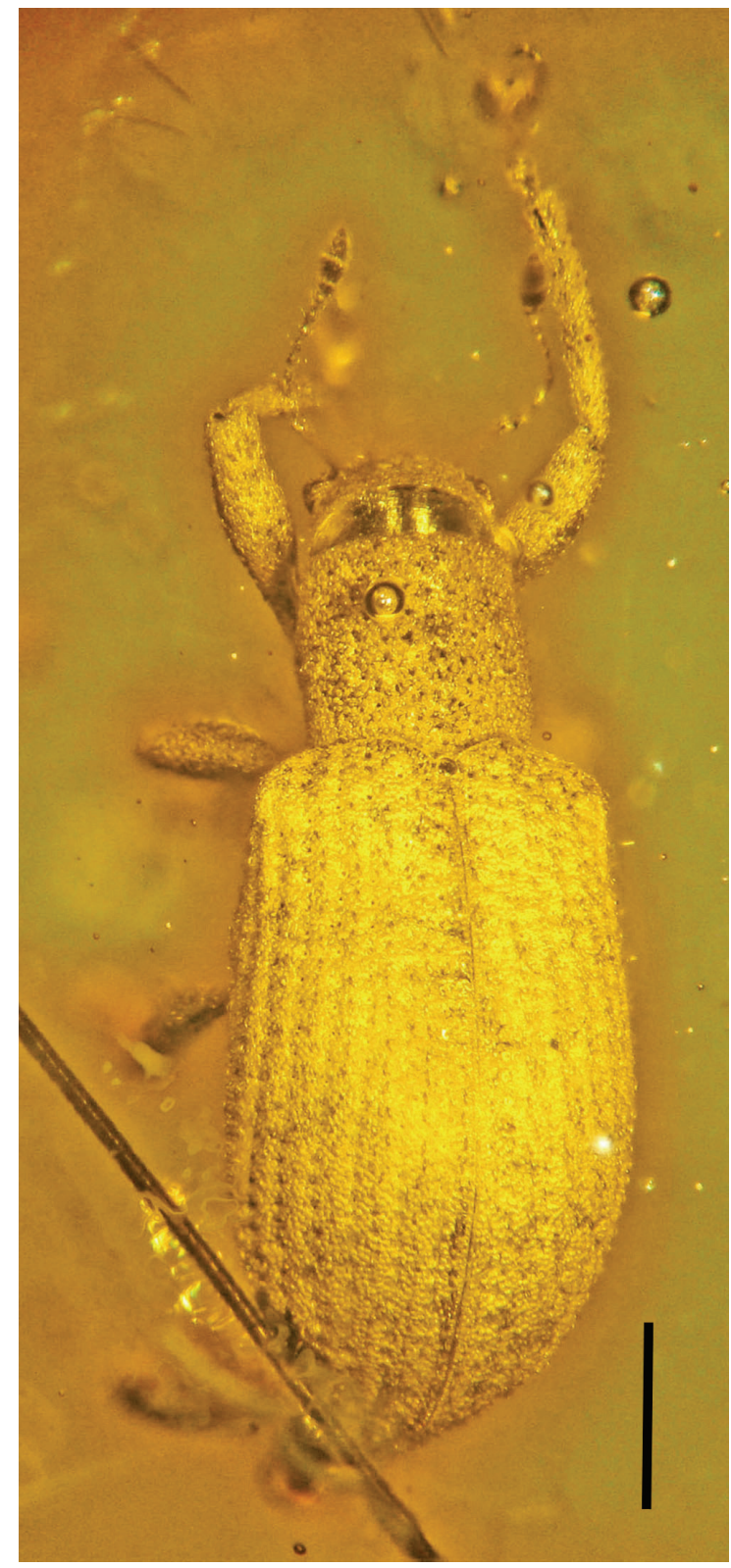

FIGURE 10. Dorsal view of Apodrosus canalinasus n. $\mathrm{sp}$. in Dominican amber. Scale bar equals $0.8 \mathrm{~mm}$. 


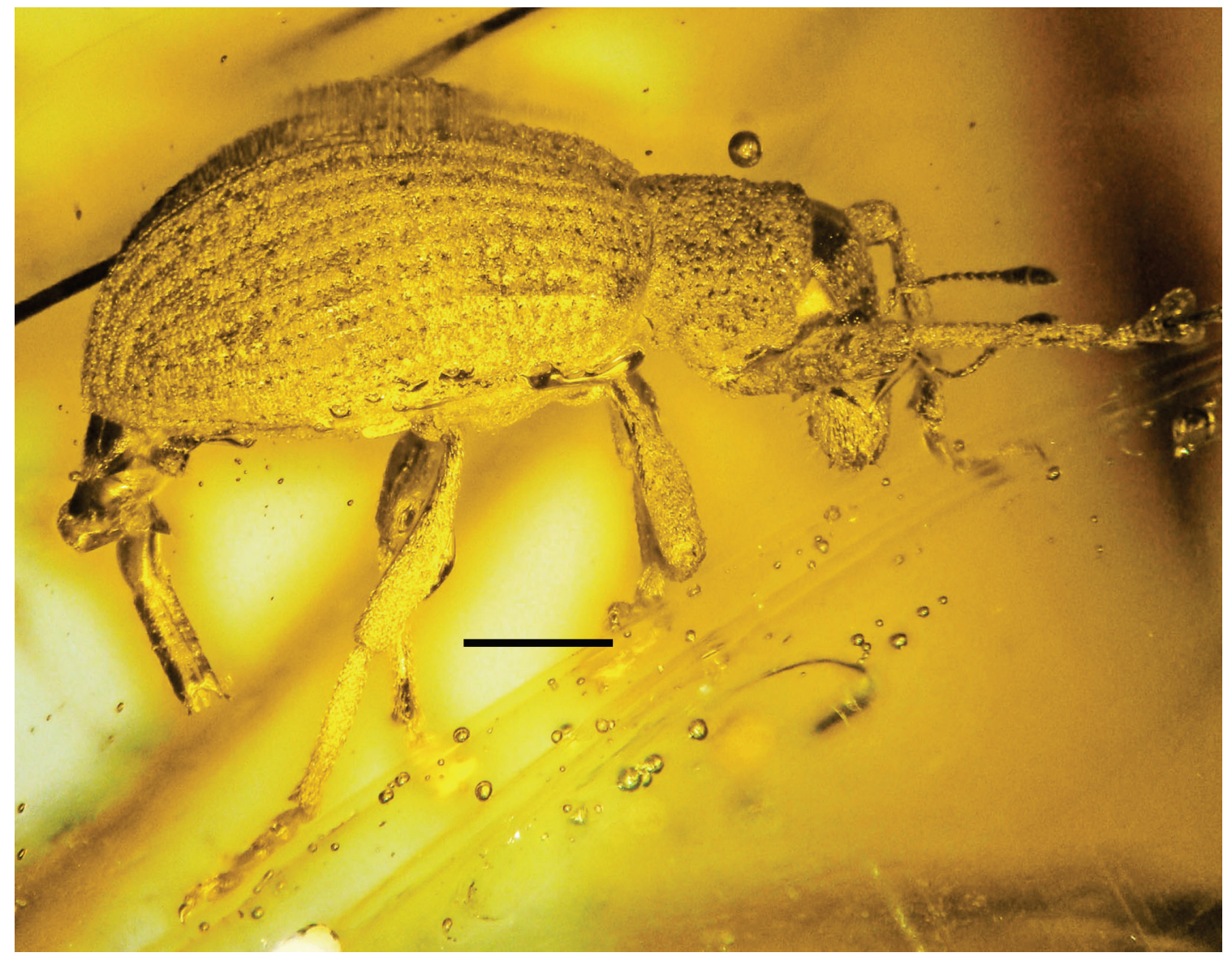

FIGURE 11. Lateral view of Apodrosus canalinasus n. sp. in Dominican amber. Scale bar equals $0.8 \mathrm{~mm}$

ing middle of pronotum; pterygia dorso-lateral; antennomeres almost conical; 1st antennomere (scape) $8.4 x$ longer than wide, reaching posterior margin of eyes; 2 nd antennomere 2.6x longer than wide, $1.0 \mathrm{x}$ as long and $0.3 \mathrm{x}$ as narrow as 1 st antennomere; 3rd antennomere 3.3x longer than wide, $0.7 x$ as long as and $0.8 x$ as narrow as 2 nd antennomere; 4th antennomere 2.3x longer than wide, $0.9 x$ as long as and $0.9 x$ as narrow as 4 th antennomere; 5 th antennomere $1.8 x$ longer than wide, $0.9 \mathrm{x}$ as long as and $1.1 \mathrm{x}$ as wide as 4 th antennomere; 6 th antennomere $1.6 \mathrm{x}$ longer than wide, $0.9 x$ as long as and equal in width to 5 th antennomere; 7 th antennomere 1.6x longer than wide, $1.1 \mathrm{x}$ as long as and $1.1 \mathrm{x}$ as wide as 6 th antennomere; 8th antennomere $1.3 x$ longer than wide, $0.9 x$ as long as and $1.1 x$ as narrow as 7 th antennomere; club compact, $3.4 x$ longer than wide, $0.6 x$ as long as flagellum, with fused articles.

Pronotum 1.1x longer than wide at apex, $0.9 x$ longer than wide in middle and at base; coarsely punctate, weakly flattened, distinctly narrower than elytral base; sides almost straight; scutellum trapezoidal.

Elytra weakly convex, $3.4 \mathrm{x}$ as long as pronotum, $2.1 \mathrm{x}$ longer than wide at base, $1.7 \mathrm{x}$ longer than wide in middle, $2.6 \mathrm{x}$ longer than wide at apical fourth; humeri convex; punctate striae distinct; intervals weakly convex, wide, 3.0-5.0x as wide as diameter of points, with rows of curved narrow scales; apical part of elytra not convex laterally.

Prosternum weakly convex, densely punctate, without postorbital lobe and vibrissae; pre- and postcoxal portions of prosternum quite long; procoxal cavities connected; metasternum weakly convex, punctate; metepisternum narrow.

Abdomen weakly flattened, finely punctate; 1st, 2nd and 5th ventrites elongate. 1st ventrite $1.5 x$ as long as metacoxal cavities length; 2 nd ventrite $1.2 x$ as long as 1 st ventrite; 3rd ventrite $0.2 x$ as long as 2 nd ventrite; 4 th ventrite equal in length to 3 rd ventrite; 5 th ventrite $2.0 x$ as long as 4 th ventrite. 
Procoxae located near middle of prosternum; mesocoxae rounded, narrowly separated; femora thickened, punctate, without teeth; prolegs not increased; profemora 4.0x longer than wide in middle; metafemora $4.7 x$ longer than wide in middle; tibiae almost straight, punctate, with mucro; protibia $6.7 x$ longer than wide in middle; metatibia 5.0x longer than wide in middle; metatibial corbel semienclosed; tarsi elongate; 1st tarsomere elongate; 2nd tarsomere conical; 3rd tarsomere bilobed; 5th tarsomere elongate; claws connate; protarsi: 1st tarsomere 1.6x longer than wide; 2nd tarsomere $0.9 \mathrm{x}$ longer than wide, $0.8 \mathrm{x}$ as long as and $1.4 \mathrm{x}$ as wide as 1st tarsomere; 3rd tarsomere $0.6 x$ longer than wide, $1.2 x$ as long as and $1.7 x$ as wide as 2 nd tarsomere; 5th tarsomere $3.0 x$ longer than wide, $1.3 x$ as long as and $0.3 x$ as wide as 3rd tarsomere. Type locality. Amber mine in the northern portion of the Dominican Republic.

Etymology. The species epithet is from the Latin "canalis" = groove and the Latin "nasus" = nose, in reference to the furrow on the rostrum.

Diagnosis. The new species is close Apodrosus viridium Girón and Franz, 2010 from Hispaniola but differs by the tibiae lacking a premucro, the body with light scales, the legs brown-black, and the eyes weakly convex.

Remarks. The semi-enclosed metatibial corbel, the rostrum and forehead with a longitudinal midfurrow and the large, naked, elevated epistoma indicate that the new species belongs to the genus Apodrosus.

Tribe EUDIAGOGINI LeConte, 1874

Genus PROMECOPS Sahlberg, 1823

Subgenus PROMECODES Marshall, 1939

Promecops (Promecodes) divarichela sp. nov. Figures 12, 13

zoobank.org/22E45BCA-7A64-46CD-A368-7B48517326B8

Holotype. Deposited in Poinar amber collection maintained at Oregon State University, Corvallis (Oregon, USA) (accession \# 154).

Description. The specimen is complete. Body length (without rostrum), $3.1 \mathrm{~mm}$; rostrum length, $0.4 \mathrm{~mm}$. Body brown-black, with appressed light scales and curved narrowed scales.

Head $0.7 x$ as long as rostrum; rostrum almost straight, short, $0.8 x$ longer than wide at apex, $0.9 x$ longer than wide in middle, 1.0x longer than wide at base, $0.7 x$ as long as pronotum, finely punctate; forehead quite wide, flat, $0.6 x$ as narrow as rostrum base width; eyes large, flat, transversely oval; temples short, $0.2 x$ as long as eye; antennal scrobes directed towards bottom of eyes, not extending beneath eyes; geniculate antennae inserted in api-

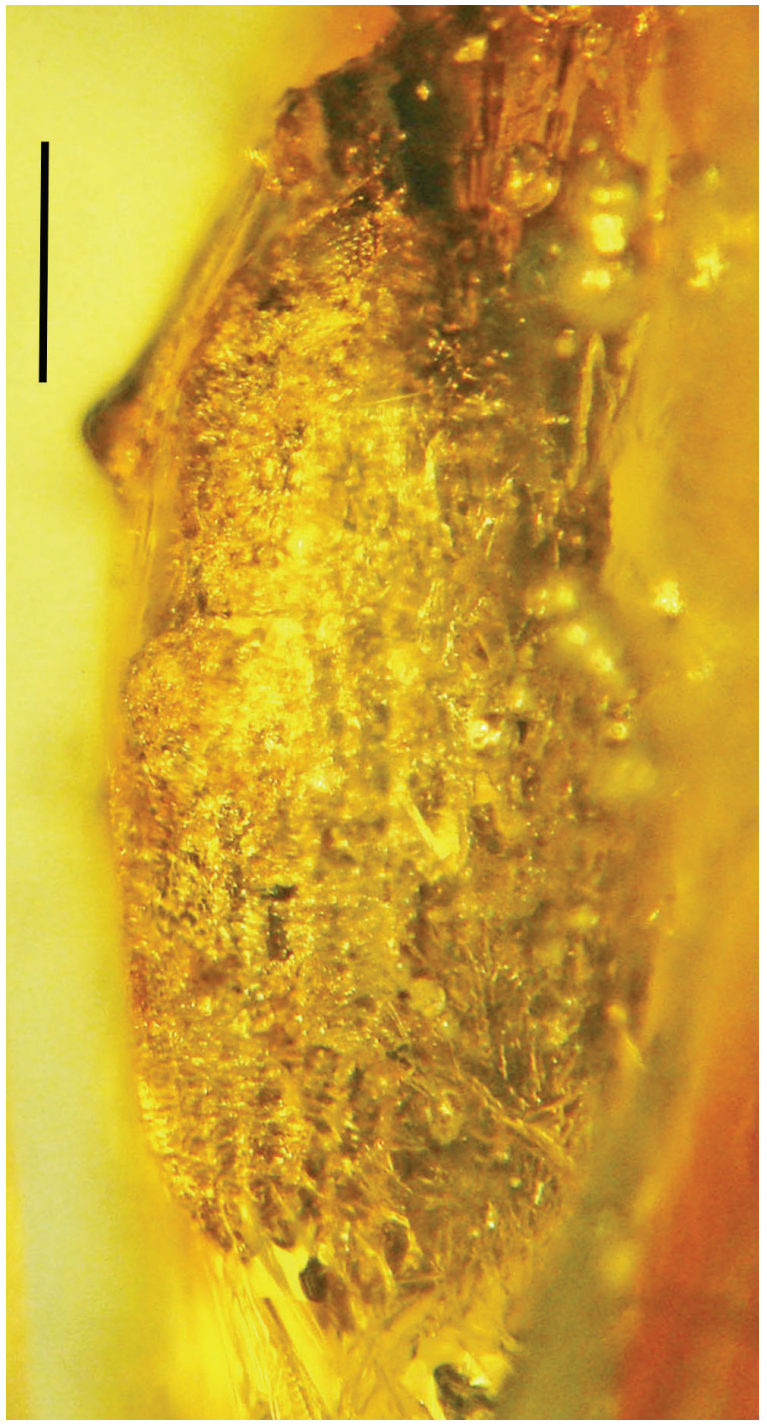

FIGURE 12. Dorsal view of Promecops (Promecodes) divarichela n. sp. in Dominican amber. Scale bar equals $0.7 \mathrm{~mm}$.

cal third of rostrum, not reaching base of pronotum; antennomeres almost conical; 4th antennomere $1.8 x$ longer than wide; 5 th antennomere $1.6 x$ longer than wide, $0.7 x$ as long as and $0.8 x$ as narrow as 4th antennomere; 5th-7th antennomeres subequal in length; 6th antennomere equal to 5th antennomere; 7 th antennomere $1.4 x$ longer than wide, $0.9 x$ as long as 6 th antennomere; 8 th antennomere equal in length and width, 1.0x as long and $1.4 \mathrm{x}$ as wide as 7 th antennomere; club compact, $4.0 x$ longer than wide, a little shorter than last four antennomeres together taken, with fused articles.

Pronotum 0.6x longer than wide at apex and in middle, $0.7 x$ longer than wide at base; densely punctate, flattened, narrower than elytral base; 


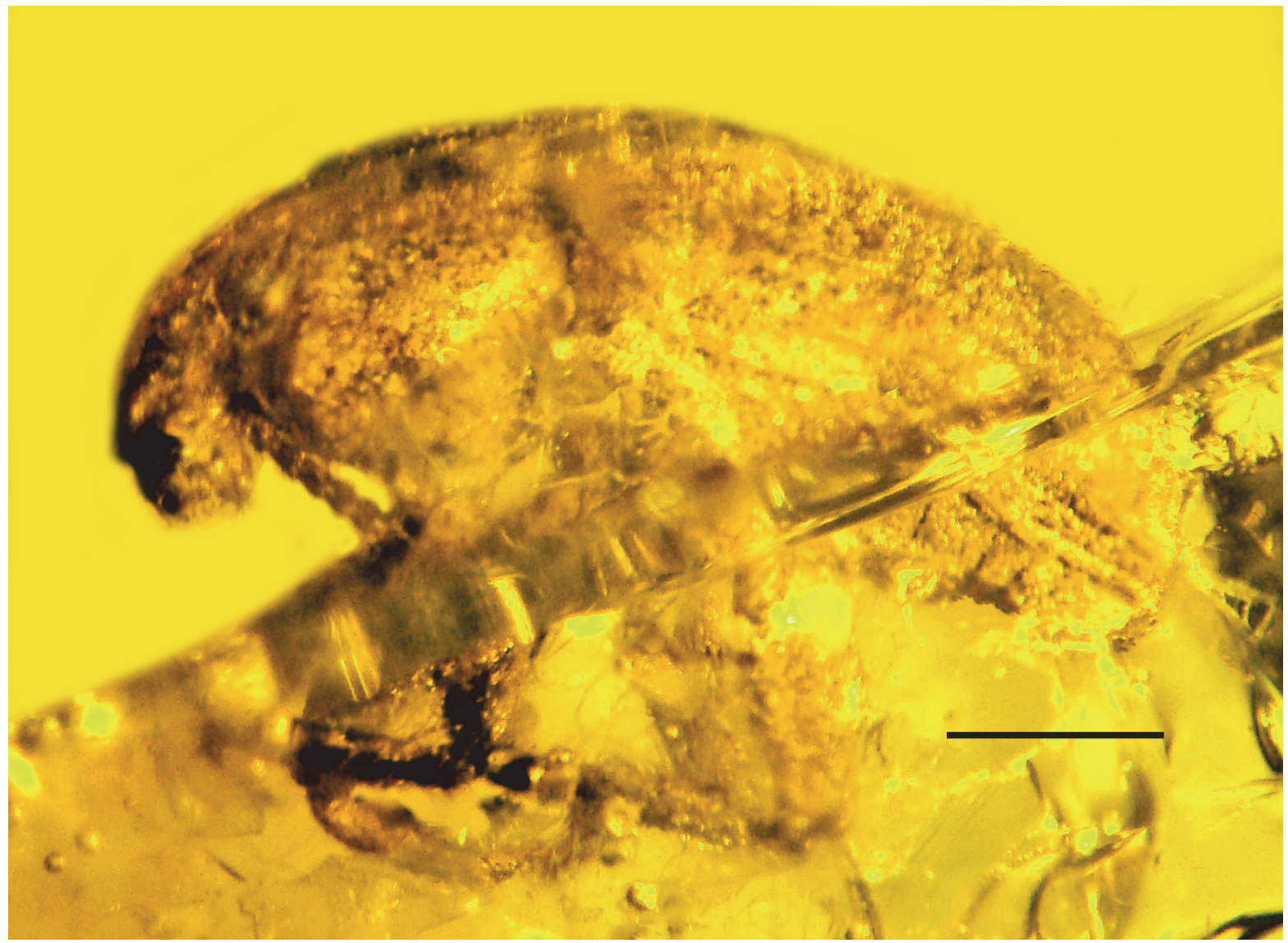

FIGURE 13. Lateral view of Promecops (Promecodes) divarichela n. sp. in Dominican amber. Scale bar equals 0.7 $\mathrm{mm}$.

sides almost rounded, expand to apex; scutellum trapezoidal.

Elytra weakly convex, $2.6 x$ as long as pronotum, $1.5 x$ longer than wide at base, $1.4 x$ longer than wide in middle, $2.1 \mathrm{x}$ longer than wide at apical fourth; humeri weakly flattened; punctate striae distinct, with quite small points; intervals weakly convex, wide, 3.0-4.0x as wide as diameter of points; apex of elytra rounded.

Prosternum weakly convex, densely punctate, with distinct postorbital lobe; ventral edge of postorbital lobe rounded, without vibrissae; preand postcoxal portions of prosternum quite short; procoxal cavities connected; mesosternum not protuberant; metasternum weakly convex, punctate; metepisternum quite narrow.

Abdomen flattened, finely punctate; 1st, 2nd, and 5 th ventrites elongate; $3 r d$ and 4 th ventrites short; 2 nd ventrite $0.6 \mathrm{x}$ as long as 1 st ventrite; 3 rd ventrite $0.4 \mathrm{x}$ as long as $2 \mathrm{nd}$ ventrite; 4 th ventrite subequal to 3 rd ventrite; 5 ventrite $2.4 x$ as long as 4 th ventrite and $0.7 x$ as long as 1 st ventrite.
Procoxae located near middle of prosternum, slightly closer to basal margin; mesocoxae rounded, narrowly separated; femora thickened, finely punctate, without teeth; tibiae almost straight, punctate, with apical setose fringe and mucro; metatibiae not widened; tarsi elongate; 1st tarsomere elongate; 2 nd tarsomere conical; 3rd tarsomere bilobed; 5th tarsomere elongate; claws free, slightly divergent, without teeth.

Type locality. Amber mine in the northern portion of the Dominican Republic.

Etymology. The species epithet is from the Latin "divarico = spread apart and the Latin "chela" = claw, in reference to the free tarsal claws.

Diagnosis. The new species is close to Promecops (Promecodes) uniformis Champion, 1911 from Guatemala but differs by the wider pronotum and elytra and much smaller body size. From $P$. (P.) alternans Champion, 1911 from Central America, it differs by the unicolored body, wider pronotum, and smaller body size. It is distinguished from the previously described Dominican amber species, Promecops (Promecops) tumidirostris Poinar 
and Brown, 2011 in the nominative subgenus by possessing free tarsal claws, a wider body, starker flattened elytral humeri, and wide elytral intervals.

Remarks. The new species belongs to the tribe Eudiagogini because it has the distinct postorbital lobes without vibrissae, antennal scrobes directed towards the bottom of the eye and short rostrum. The pronotum with rounded sides narrower than the elytral base, metatibiae not widened and elytra with humeri are characters of the genus Promecops. This species is a member of the subgenus Promecodes based on the free tarsal claws.

\section{DISCUSSION}

Representatives of the tribe Eustylini are poorly represented in the fossil record (Legalov, 2015). Only one species of the genus Lachnopus is known from the terminal Eocene (Scudder, 1893). Several species of the modern status "incertae sedis" are described in the genus Lachnopus from the Oligocene of Germany and Miocene of France (Legalov, 2015). The tribe Eustylini is only known in the New World. The extent of the tribe and phylogenetic relationships have been recently studied (Franz, 2010, 2012; Girón and Franz, 2012). The genera Diaprepes and Lachnopus are represented by several species in Hispaniola (Perez-Gelabert, 2008) but this is the first record of a fossil of the genus Diaprepes.

The status of the genus Apodrosus is unclear. It is placed provisionally in the tribe Polydrusini because of the connate claws, but it is closer to representatives of the tribe Anypotactini by the structure of the epistoma and metatibial corbels (Girón and Franz, 2010). Two fossil Polydrusini species from the Eocene and Miocene are known and representatives ( 6 species of 3 genera) of the tribe Anypotactini are known from Eocene deposits (Legalov, 2015).

The tribe Eudiagogini is distributed only in the New World and includes about 100 species in 10 recent genera (O'Brien and Wibmer, 1982; Wibmer and O'Brien, 1986). This group has been well studied (Voss, 1934, 1953). Two fossil species (the Eocene Oligocryptus sectus Scudder, 1893 and the Miocene Promecops tumidirostris Poinar and Brown, 2011) are known. This tribe is absent in the modern fauna of Hispaniola (Perez-Gelabert, 2008).

\section{ACKNOWLEDGMENTS}

We are grateful to B.A. Korotyaev (Russia: St. Petersburg), N.B. Nikitsky (Russia: Moscow) and
A. Yu. Solodovnikov (Denmark: Copenhagen) for the opportunity to study comparative material deposited in the Natural History Museum of Denmark (Copenhagen), Zoological Institute RAS (St. Petersburg), and Zoological Museum of Moscow University, and to J. Hájek (Czech Republic: Praha) and D.V. Logunov (UK: Manchester) for help with the literature. The study was partially supported by the Federal Fundamental Scientific Research Programme for 2013-2020, project no. VI.51.1 and the Russian Foundation for Basic Research, project no. 15-04-02971a.

\section{REFERENCES}

Champion, G.C. 1911. Insecta. Coleoptera. Rhynchophora. Curculionidae. Otiorhynchinae. Biologia Centrali-Americana, 4:313-354.

Draper, G., Mann, P., and Lewis, J.F. 1994. Hispaniola, p. 129-150. In Donovan, S. and Jackson, T.A. (eds.), Caribbean Geology: An Introduction. The University of the West Indies Publishers' Association, Kingston, Jamaica.

Franz, N.M. 2010. Redescriptions of critical type species in the Eustylini Lacordaire (Coleoptera: Curculionidae: Entiminae). Journal of Natural History, 44:41-80.

Franz, N.M. 2012. Phylogenetic reassessment of the Exophthalmus genus complex (Curculionidae: Entiminae: Eustylini, Geonemini). Zoological Journal of the Linnean Society, 164:510-557.

Girón, J.C. and Franz, N.M. 2010. Revision, phylogeny and historical biogeography of the genus Apodrosus Marshall, 1922 (Coleoptera: Curculionidae: Entiminae). Insect Systematics \& Evolution, 41:339-414.

Girón, J.C. and Franz, N.M. 2012. Phylogenetic assessment of the Caribbean weevil genus Lachnopus Schoenherr (Coleoptera: Curculionidae: Entiminae: Geonemini). Invertebrate Systematics, 26:67-82.

Gyllenhal, L. 1834. [Title and pages unknown]. In Schoenherr, C.J. (ed.), Genera et species curculionidum, cum synonymia hujus familiae. Species novae aut hactenus minus cognitae, descriptionibus a Dom. Leonardo Gyllenhal. C. H. Boheman, et entomologis aliis illustratae. 2(1-2). Roret, Paris. (In Latin)

Hong, Y. 2002. Amber Insects of China. Beijing Science and Technology Press, Beijing. (In Chinese)

Iturralde-Vinent, M.A. and MacPhee, R.D.E. 1996. Age and paleogeographic origin of Dominican amber. Science, 273:1850-1852.

Lacordaire, T. 1863. Histoire Naturelle des Insectes. Genera des Coléoptères ou exposé méthodique et critique de tous les genres proposés jusqu'ici dans cet ordre d'insectes. Vol. 6. Roret, Paris. (In French)

LeConte, J.L. 1874. The classification of the rhynchophorous Coleoptera. American Naturalist, 8:385-396, 452-470. 
Legalov, A.A. 2012. Fossil history of Mesozoic weevils (Coleoptera: Curculionoidea). Insect Science, 19:683-698.

Legalov, A.A. 2014. The oldest Brentidae and Curculionidae (Coleoptera: Curculionoidea) from the Aptian of Bon-Tsagaan. Historical Biology, 26:6-15.

Legalov, A.A. 2015. Fossil Mesozoic and Cenozoic weevils (Coleoptera, Obrienioidea, Curculionoidea). Paleontological Journal, 49:1442-1513.

Marshall, G.A.K. 1922. Some injurious Neotropical weevils (Curculionidae). Bulletin of Entomological Research, 13:59-71.

Marshall, G.A.K. 1939. New tropical African Curculionidae (Col.). Annals and Magazine of Natural History, 11:561-583.

O'Brien, C.W. and Wibmer, C.J. 1982. Annotated checklist of the weevils (Curculionidae sensu latu) of North America, Central America and the West Indies (Coleoptera: Curculionoidea). Memoirs of the American Entomological Institute, 34:1-382.

Olivier, A.G. 1790. Encyclopédie méthodique. Historie naturelle. Insectes. Vol. 5. Panckoucke, Paris. (In Latin)

Olivier, A.G. 1807. Entomologie, ou Histoire Naturelle des Insectes, avec leurs caractères génériques et spécifiques, leur description, leur synonymie, et leur figure enluminée. Coléoptères. Vol. 5. Desray, Paris. (In Latin)

Perez-Gelabert, D.E. 2008. Arthropods of Hispaniola (Dominican Republic and Haiti): a checklist and bibliography. Zootaxa, 1831:1-530.

Poinar, G.O., Jr. 1991. Hymenaea protera sp. n. (Leguminosae, Caesalpinioideae) from Dominican amber has African affinities. Experientia, 47:1075-1082.

Poinar, G., Jr. and Brown, A.E. 2011. Descriptions of a broad-nosed weevil (Eudiagogini: Curculionidae) and false ladybird beetle (Nilionini: Nilionidae) in Dominican amber. Historical Biology, 23:231-235.

Poinar, G.O., Jr., Legalov, A.A., and Brown, A.E. 2013. Brachycamacina, a new subtribe of the tribe Naupactini (Coleoptera: Curculionidae: Entiminae) in Dominican amber. Palaeontologia Electronica, 16.3.24A:19 palaeo-electronica.org/content/2013/531-new-weevil-tribe
Poinar, G.O., Jr. and Mastalerz, M. 2000. Taphonomy of fossilized resins: determining the biostratinomy of amber. Acta Geologica Hispanica, 35:171-182.

Poinar, G.O., Jr. and Poinar. R. 1999. The Amber Forest. Princeton University Press, Princeton, New Jersey.

Sahlberg, C.R. 1823. Periculi Entomographici, species Insectorum nondum descriptas proposituri, fascicuIus. Aboae, Typis Frenckelliorum. (In Latin)

Schlee, D. 1990. Das Bernstein-Kabinett. Begleitheft zur Bernsteinausstellung im Museum am Löwentor, Stuttgart, 28:1-100. (In German)

Schoenherr, C.J. 1823. Curculionides [Tabula synoptica familiae Curculionidum]. Isis von Oken, 1823:11321146. (In Latin)

Schoenherr, C.J. 1840. Genera et species curculionidum, cum synonymia hujus familiae. Species novae aut hactenus minus cognitae, descriptionibus a Dom. Leonardo Gyllenhal, C. H. Boheman, et entomologis aliis illustratae. Vol. 5(2). Roret, Paris. (In Latin)

Scudder, S.H. 1893. Tertiary Rhynchophorous Coleoptera of the United States. Monographs of the United States Geological Survey, 21:1-206.

Yunakov, N.N. and Kirejtshuk, A.G. 2011. New genus and species of broad-nosed weevils from Baltic amber and notes on fossils of the subfamily Entiminae (Coleoptera, Curculionidae). ZooKeys, 160:7396.

van Emden, F.I. 1944. A key to the genera of Brachyderinae of the world. Annals and Magazine of Natural History, 11:503-532, 559-586.

Voss, E. 1934. Einige unbeschriebene Neotropische Curculioniden nebst einer Vorstudie zur Tribus Promecopini. 48. Beitrage zur Kenntnis der Curculioniden. Sbornik Entomologikeho Oddeleni Narodniho Musea v Praze, 12:63-104. (In German)

Voss, E. 1953. Ergänzende Ausführungen zur Gattung Promecops Schoenh. und Pseudeudius Voss an hand typischer Exemplare aus dem Riksmuseum Stockholm. Arkiv för Zoologi, 4:423-438. (In German) Wibmer, G.J. and O'Brien, C.W. 1986. Annotated checklist of the weevils (Curculionidae sensu lato) of South America (Coleoptera: Curculionoidea). Memoirs of the American Entomological Institute, 39:1-563. 